\title{
True's beaked whale (Mesoplodon mirus) in Macaronesia
}

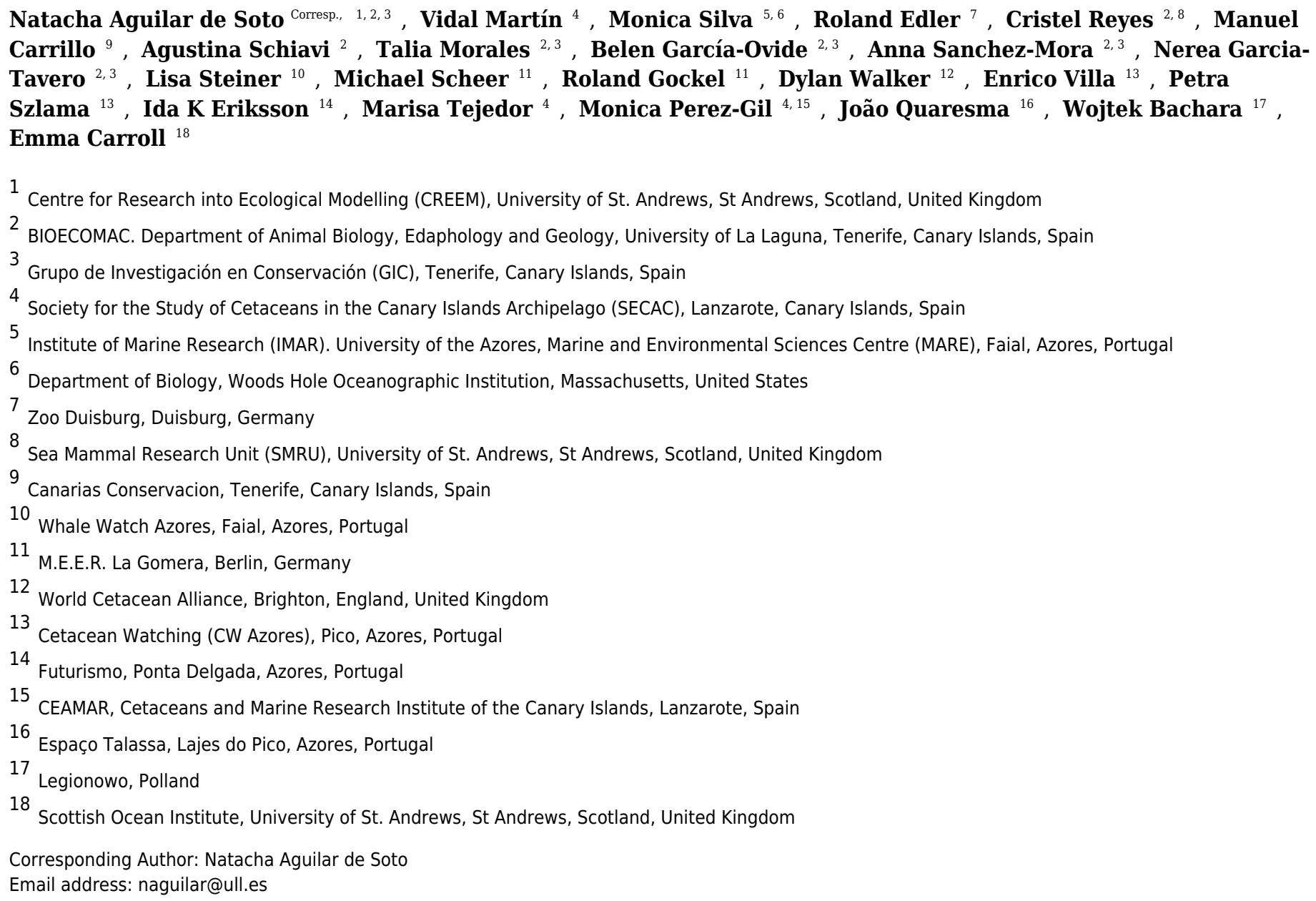

The True's beaked whale (Mesoplodon mirus, True 1913) is a poorly known member of the Ziphiidae family. Its distribution in the northern hemisphere is thought to be restricted to the temperate or warm temperate waters of the North Atlantic, while a few stranding records from the southern hemisphere suggest a wider and antitropical distribution, extending to waters from the Atlantic coast of Brazil to South Africa, Mozambique, Australia and the Tasman Sea coast of New Zealand. This paper i) reports the first molecular confirmation of the occurrence of the True's beaked whale at the southern limit of its distribution recorded in the northeast Atlantic: the Azores and Canary Islands (macaronesian ecoregion); ii) describes a new colouration for this species using evidence from a whale with molecular species confirmation; and iii) contributes to the sparse worldwide database of live sightings, including the first underwater video recording of this species and close images of a calf. Species identification was confirmed in two cases using mitochondrial DNA control region and cytochrome $b$ gene markers: a subadult male True's 
beaked whale that stranded in El Hierro, Canary Islands, in November 2012, and a subadult male found floating dead near Faial, the Azores, in July 2004. The whale that stranded in the Canary Islands had a clearly delimited white area on its head, extending posteriorly from the tip of the beak to cover the blowhole dorsally and the gular grooves ventrally. This colouration contrasts with previous descriptions for the species and it may be rare, but it exemplifies the variability of the colouration of True's beaked whales in the North Atlantic, further confirmed here by live sightings data. The recording of several observations of this species in deep but relatively coastal waters off the Azores and the Canary Islands suggests that these archipelagos may be unique locations to study the behaviour of the enigmatic True's beaked whale. 


\section{True's beaked whale (Mesoplodon mirus) in Macaronesia}

1 Natacha Aguilar de Soto*1,2,3, Vidal Martín ${ }^{4}$, Mónica A. Silva ${ }^{5,6}$, Roland Edler ${ }^{7}$, Cristel Reyes ${ }^{1,8}$,

2 Manuel Carrillo $^{9}$, Agustina Schiavi ${ }^{1}$, Talía Morales ${ }^{1,3}$, Belén García-Ovide ${ }^{1,3}$, Anna Sánchez ${ }^{1,3}$, Ne-

3 rea García-Tavero ${ }^{1,3}$, Lisa Steiner ${ }^{10}$, Michael Scheer ${ }^{11}$, Roland Gockel ${ }^{11}$, Dylan Walker ${ }^{12}$, Enrico

4 Villa $^{13}$, Petra Szlama ${ }^{13}$, Ida K. Eriksson ${ }^{14}$, Marisa Tejedor ${ }^{4}$, Mónica Pérez Gil ${ }^{4,15}$, João Quaresma ${ }^{16}$,

5 Wojtek Bachara ${ }^{17}$, Emma L. Carroll ${ }^{18}$

6 1. BIOECOMAC. Department of Animal Biology, Edaphology and Geology. University of

$7 \quad$ La Laguna. Tenerife. Canary Islands. Spain.

8 2. Centre for Research in Ecological Modelling (CREEM). University of St Andrews. St.

$9 \quad$ Andrews Scotland. UK.

10 3. Grupo de Investigación en Conservación (GIC). Tenerife. Canary Islands. Spain

11 4. Society for the Study of Cetaceans in the Canary Islands (SECAC). Arrecife. Lanzarote.

12 Canary Islands. Spain.

13 5. Marine and Environmental Sciences Centre (MARE). Institute of Marine Research 14 (IMAR). University of the Azores. Faial. Portugal.

15 6. Woods Hole Oceanographic Institution (WHOI). Department of Biology. Massachusetts.

$16 \quad$ USA.

17 7. Zoo Duisburg. Duisburg. Germany.

18 8. Sea Mammal Research Unit (SMRU), University of St Andrews. Scotland. UK.

19 9. Canarias Conservación. Tenerife. Canary Islands. Spain.

20 10. Whale Watch Azores. Horta. Faial. Azores. Portugal.

21 11. M.E.E.R. La Gomera. Berlin. Germany.

22 12. World Cetacean Alliance. Brighton. England. UK.

23 13. Cetacean Watching (CW Azores). Madalena. Pico. Azores. Portugal.

24 14. Futurismo. Ponta Delgada. Azores. Portugal. 
25 15. Cetaceans and Marine Research Institute of the Canary Islands (CEAMAR). Lanzarote.

26 Canary Islands. Spain.

27 16. Espaço Talassa. Lajes do Pico, Azores, Portugal.

28 17. Legionowo. Poland.

29 18. School of Biology, Scottish Ocean Institute, University of St Andrews. Scotland. UK.

30 *Corresponding author. Name: Natacha. Surname: Aguilar de Soto. naguilar@ull.es

\section{ABSTRACT}

32 The True's beaked whale (Mesoplodon mirus, True 1913) is a poorly known member of the

33 Ziphiidae family. Its distribution in the northern hemisphere is thought to be restricted to the

34 temperate or warm temperate waters of the North Atlantic, while a few stranding records from the

35 southern hemisphere suggest a wider and antitropical distribution, extending to waters from the

36 Atlantic coast of Brazil to South Africa, Mozambique, Australia and the Tasman Sea coast of

37 New Zealand. This paper i) reports the first molecular confirmation of the occurrence of the True

38 's beaked whale at the southern limit of its distribution recorded in the northeast Atlantic: the

39 Azores and Canary Islands (macaronesian ecoregion); ii) describes a new colouration for this

40 species using evidence from a whale with molecular species confirmation; and iii) contributes to

41 the sparse worldwide database of live sightings, including the first underwater video recording of

42 this species and close images of a calf. Species identification was confirmed in two cases using

43 mitochondrial DNA control region and cytochrome $b$ gene markers: a subadult male True's

44 beaked whale that stranded in El Hierro, Canary Islands, in November 2012, and a subadult male

45 found floating dead near Faial, the Azores, in July 2004. The whale that stranded in the Canary

46 Islands had a clearly delimited white area on its head, extending posteriorly from the tip of the

47 beak to cover the blowhole dorsally and the gular grooves ventrally. This colouration contrasts

48 with previous descriptions for the species and it may be rare, but it exemplifies the variability of 
49 the colouration of True's beaked whales in the North Atlantic, further confirmed here by live

50 sightings data. The recording of several observations of this species in deep but relatively coastal

51 waters off the Azores and the Canary Islands suggests that these archipelagos may be unique

52 locations to study the behaviour of the enigmatic True's beaked whale.

\section{INTRODUCTION}

54 Studies on animal distribution rely on the correct identification of the focal species during 55 surveys. This can be challenging for marine mammals that are present at the sea surface for short

56 time periods, particularly when they share colouration patterns and morphology with closely

57 related species. These challenges are exemplified by the family ziphiidae, which contains 22

58 species of beaked whales. Within ziphiids, species of the genus Mesoplodon have been proposed

59 as some of the most poorly known of all the genera of large mammals (Jefferson et al., 2015).

60 Ziphiids dive to depth for long periods of time, with only short breathing intervals at the sea

61 surface (Tyack et al., 2006; Aguilar de Soto et al., 2012). Furthermore, they show large

62 intraspecific variability in colouration and interspecific similarities in general morphology,

63 including colouration patterns (Mead, 2009; Jefferson et al., 2015). Due to the inherent

64 difficulties in identifying beaked whales to species level at sea, sightings of different ziphiid

65 species are often pooled for analyses of survey data (e.g. Moore \& Barlow, 2013). This results in

66 a loss of precision in our knowledge about the distribution of individual species.

67 Beaked whales are broadly distributed in all oceans of the world. Six species of three genera can

68 be found regularly in the North Atlantic: Cuvier's beaked whales $(\sim 5-7 \mathrm{~m})$ and northern

69 bottlenose whales ( 9-10 m) (Ziphius cavirostris and Hyperoodon ampullatus, respectively), and

70 four species of the genus Mesoplodon ( 4.5-5.5 m): Blainville's, Sowerby's, Gervais' and True's

71 beaked whales (M. densirostris, M. bidens, M. europaeus and M. mirus, respectively) (MacLeod

72 et al., 2006). The large size and distinctive head morphology of Cuvier's beaked whales and 
73 bottlenose whales facilitate their differentiation at sea. In addition, adult Cuvier's beaked whales

74 often show clear colour patches in the head, dorsum and other parts of the body, and this provides

75 a further identification cue (examples at www.cetabase.info). Mesoplodonts are similar in size

76 and often difficult to identify at sea to species level. The position of the teeth along the lower jaw

77 is the most reliable cue to distinguish adult males at sea. Females and subadult males do not have

78 erupted teeth but the location of alveoli in the lower jaw, diagnostic of species identity, can be

79 uncovered during necropsy of stranded whales (Jefferson et al., 2015). Beak and melon size and

80 shape can be used as defining characteristics of the Mesoplodont species. For example, both

81 Blainville's and Sowerby's beaked whales have relatively long beaks. However, these species can

82 be distinguished in the field, as an arched lower jaw with protruding teeth often covered in

83 barnacles is typical of the male Blainville's beaked whales, while a bulky melon and thin long

84 beak are characteristic of Sowerby's beaked whales (Jefferson \& Pitman 2015, Mead 1989). In

85 addition, the distribution of these two species seems to only partially overlap, with the former

86 preferring warmer waters than the latter (MacLeod et al., 2006). True's and Gervais' beaked

87 whales can share a general grey colouration including a dark eye patch and a pale ventral area in

88 some cases; both have shorter, mostly straight beaks. These two species are very difficult to

89 distinguish at sea. The position of the teeth in the jaw of males provide the most definitive cue

90 but teeth, even when present, are not always easy to observe at sea. A species-defining

91 characteristic is the melon, which is bulbous and well defined in Sowerby's beaked whales and

92 also in True's beaked whales, albeit less pronounced in the latter. In contrast, the melon of

93 Gervais' and Blainville's beaked whales slopes gently towards the beak (Weir et al., 2004).

94 Live sightings of many beaked whale species are rare events and just a few have been made for

95 True's beaked whales. Only three live sightings have been reported in the peer-reviewed

96 literature for the North Atlantic (Weir et al., 2004) and some (Tove, 1995) may be misidentified

97 Gervais' beaked whales. The distribution of True's beaked whales was once thought to be 
98 restricted to temperate or warm-temperate waters of the North Atlantic. However, strandings of

99 animals in South Africa (McCann and Talbot, 1964; Ross, 1969, 1984), Mozambique (Bachara \&

100 Gullan, 2016), Australia (Dixon \& Frigo, 1994), and Brazil (Mead, 1989; de Souza et al., 2004),

101 revised in MacLeod et al., (2006), as well as in New Zealand (Constantine et al., 2014), extended

102 its known range to temperate waters of the Southern Indian and South Atlantic Oceans and the

103 Tasman Sea. Thus, True's beaked whales have an antitropical distribution that is unique among

104 ziphiids (Mead, 1989; MacLeod et al., 2006). In the North Atlantic, the southernmost limit of the

105 distribution of True's beaked whales is Macaronesia. The macaronesian ecoregion contains the

106 Azores, Madeira and Canary Islands archipelagos (Spalding et al., 2007). For highly migratory

107 species, it has been proposed that the southern Cape Verde archipelago should also be included in

108 the ecoregion (Brito Hernández, 2010). In the Azores, a $3.7 \mathrm{~m}$ long subadult male True's beaked

109 whale with unerupted teeth was found dead in 2004, drifting south of the Faial-Pico channel

110 (Silva et al., 2014). In the Canary Islands, a $5 \mathrm{~m}$ long adult male True's beaked whale stranded in

1111984 on the island of Lanzarote (Vonk \& Martin, 1988). Both animals were identified as True's

112 beaked whales by their general morphology. The species has neither been recorded in Madeira

113 (Freitas et al., 2012) nor Cape Verde archipelagos (Hazevoet et al., 2010).

114 Molecular markers are highly useful to diagnose species among cetaceans (Ross et al., 2003) and

115 often more definitive than morphological characteristics that can be difficult to distinguish at sea

116 or when animals strand in a decomposed state (e.g. Dalebout et al., 2002; Constantine et al.

117 2014). This is particularly applicable to beaked whales (Dalebout et al., 2004; Thompson et al.,

118 2013). This paper reports the first occurrence of True's beaked whales in the Canary Islands and

119 the Azores confirmed with molecular markers. Furthermore, the whale that stranded in the

120 Canary Islands showed a colouration pattern that has not been previously described for this

121 species. These findings are augmented with new live sighting data of True's beaked whales off

122 the Azores and the Canary Islands, suggesting that these archipelagos are potentially good areas 
123 to study the natural behaviour of this species. Sightings are supported with video and

124 photographic material including the first underwater recording of True's beaked whales in the

125 wild and close-up images of a calf.

\section{METHODS}

127 Strandings and genetic analysis.

128 A $3.9 \mathrm{~m}$ long beaked whale stranded at Timijiraque, El Hierro, the Canary Islands, on 30

129 November 2012 (Figure 1). Observers at the beach reported that the animal might have live-

130 stranded. The whale was identified as an immature male True's beaked whale by its external

131 morphology. No teeth had erupted nor were any present in the lower jaw. A $3.7 \mathrm{~m}$ long subadult

132 male was found drifting south of the Faial-Pico channel, the Azores, on 11 July 2004 (Silva et al.,

133 2014) (Figure 2). It was identified to species-level by its general morphology and two small non-

134 erupted teeth in the tip of the lower jaw.

135 Skin samples were taken from both carcasses and preserved in 95\% ethanol. Total genomic DNA 136 was isolated using standard proteinase $\mathrm{K}$ digestion and phenol/chloroform methods (Sambrook et

137 al., 1989) or a DNeasy kit (Qiagen). Sex was confirmed by amplification of the male-specific

$138 S R Y$ gene, multiplexed with an amplification of the $Z F Y / Z F X$ region as a positive control (Aasen

139 \& Medrano, 1990; Gilson et al., 1998). In order to confirm species identification, we amplified

140 regions of both the mitochondrial DNA (mtDNA) control region and cytochrome $b$ gene using

141 polymerase chain reaction (PCR). Approximately $300 \mathrm{bp}$ of the mtDNA control region were

142 amplified using primers M13dlp1.5 (Baker et al., 1998) and Dlp4-H (Dalebout et al., 2005) and

143 approximately 200 bp of the cytochrome $b$ gene using CYBMF-L and CYBMR-H primers

144 following standard protocols (Dalebout, 2002). These short fragments were targeted because the

145 tissue, and hence DNA, was degraded as samples were collected sometime after death. PCR 146 products were purified for sequencing with AMPURE $^{\mathrm{XP}}$ (Agilent) and sequenced with BigDye ${ }^{\mathrm{TM}}$ 
147 v3.1 Terminator Chemistry (Applied Biosystems) on an ABI 3130 XL. Resulting sequences were

148 aligned against other beaked whale mtDNA sequences and edited by eye in Geneious v7

149 (http://www.geneious.com, Kearse et al., 2012) for sequence quality. Species identification was

150 made using the DNA surveillance website, constructing a neighbour joining tree with the support

151 of 1000 bootstraps (Ross et al., 2003), and by comparing the target sequences with other beaked

152 whale sequences available from GenBank using blast (Altschul et al. 1990;

153 http://www.ncbi.nlm.nih.gov/genbank/) (Dalebout et al., 2004). A $3.5 \mathrm{~m}$ immature female True's

154 beaked whale was found stranded in Fuerteventura, Canary Islands, in 2004 (Figure 3) and

155 identified initially as Gervais's beaked whale, but then re-classified as True's due to the typical

156 mouthline of the species and general morphology. This female stranded with fishing gear (long-

157 line) entangled in the caudal peduncle. No tissue was preserved for molecular analysis.

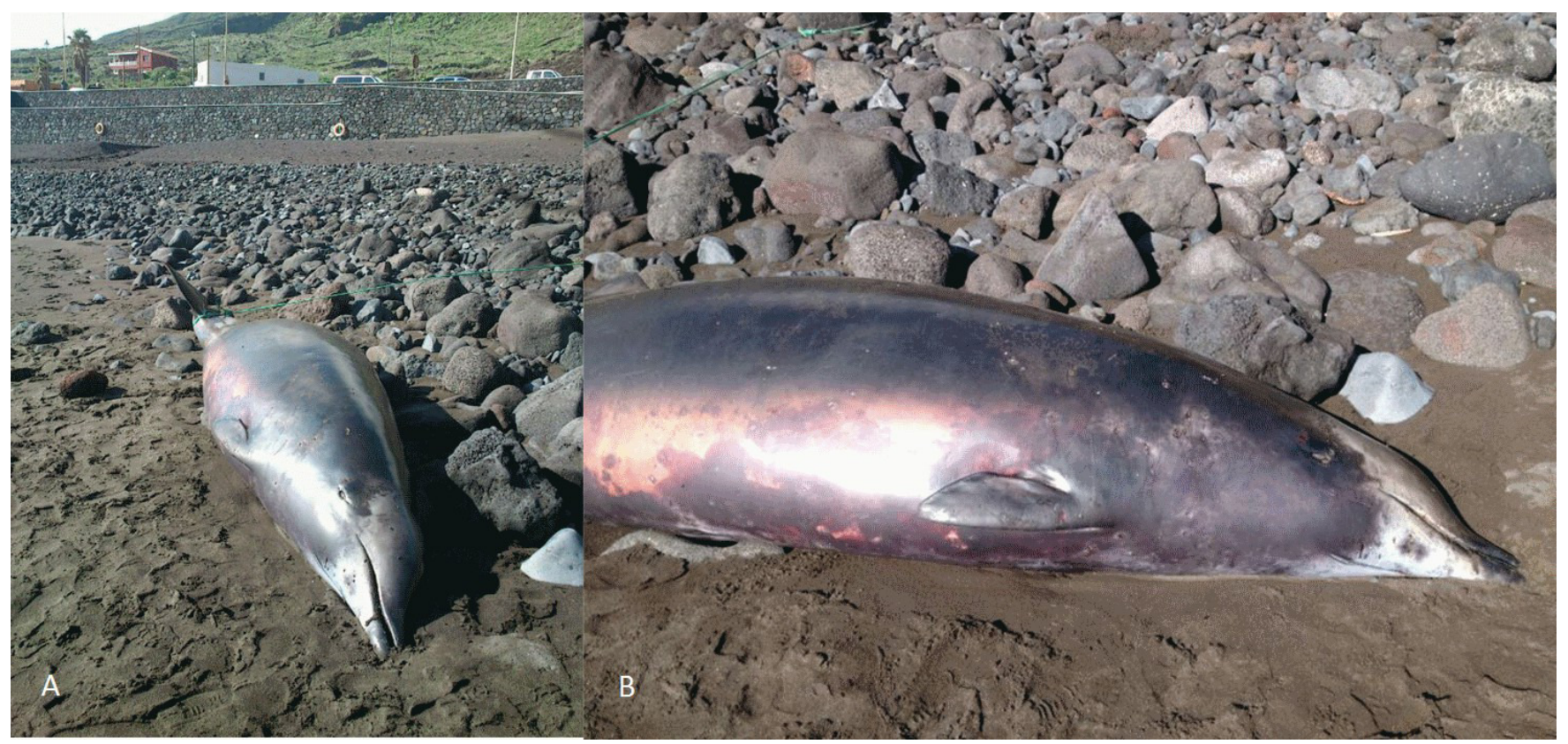

158 Figure 1: True's beaked whale stranded at El Hierro (Canary Islands) in 2010 showing a head

159 colouration not described previously for this species (report 6 Table 1). Photos: Baudilio

160 Quintero. 


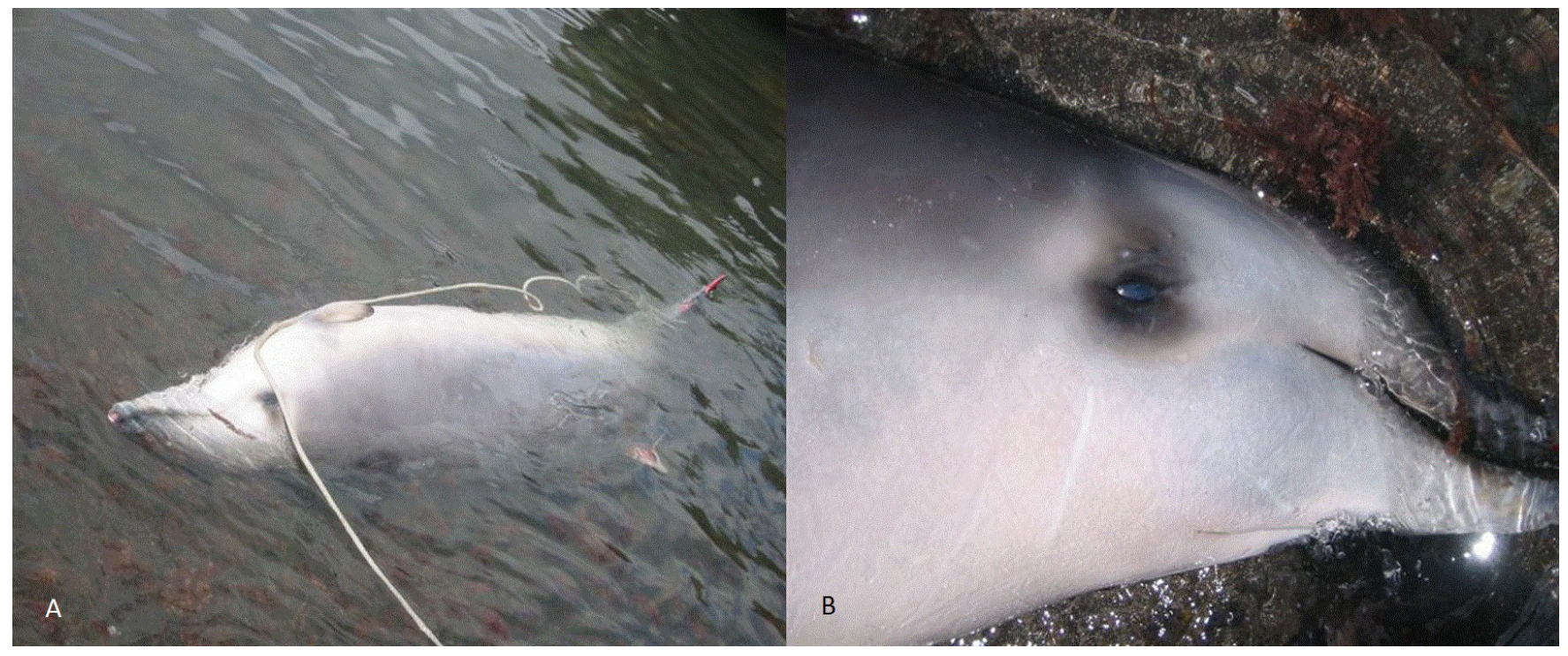

161 Figure 2:True's beaked whale found drifting south of Pico-Faial channel (the Azores) in 2004

162 (report 4 Table 1). Photo: Mónica Silva (MARES-IMAR. UA)

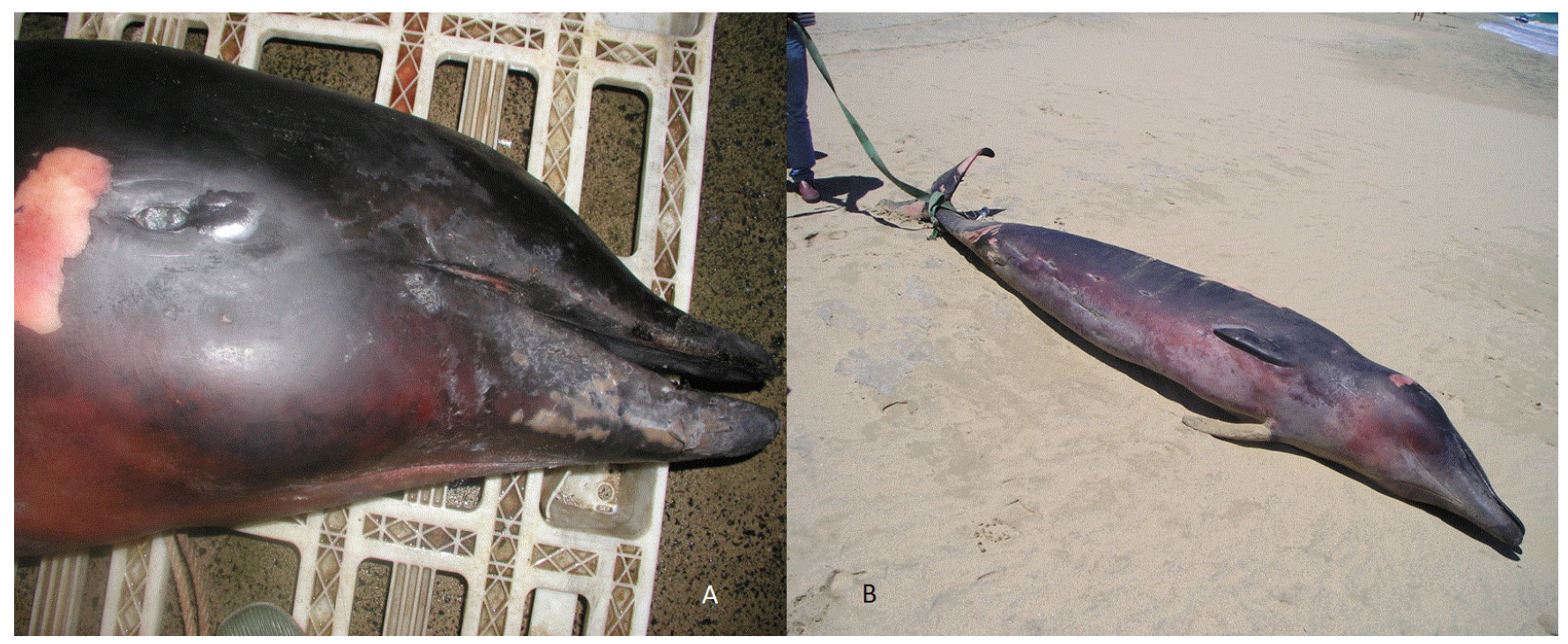

163 Figure 3: True's beaked whale stranded at Fuerteventura (Canary Islands) in 2004 (report 3 Table

164 1). Photo: Vidal Martín (SECAC). 
166 Here we report data on eight live sightings of True's beaked whales in Macaronesia (Table 1).

167 Sightings were categorised as sure $(n=5)$ or possible $(n=3)$ True's beaked whales by close

168 inspection of the colouration and morphology of the whales in the photographs taken during

169 surveys. Teeth were observed in only one individual. This, and the poor quality of the

170 photographs in some of the sightings, made identification challenging. Photos of live sightings

171 were sharpened and their contrast augmented with software packages Photoshop and GIMP.

172 Five live sightings (four classified as sure) were recorded in the Azores. One of these sightings

173 (report 8 in Table 1) occurred during a field cruise of the educational program Master Mint

174 (www.master-mint.de). A group of 3 beaked whales surfaced and milled near a drifting small

175 inflatable boat for about $10 \mathrm{~min}$, breathing every $9.7 \mathrm{~s}$ on average. This allowed the observers to

176 film the animals underwater (Figure 4 and Supporting Information - SI Video 1) providing high-

177 quality images for species identification. Shorter sightings were recorded in the Azores by whale

178 watching companies (Table 1, Figures 5 to 8).

179 Figure 4: True's beaked whale observed off Pico showing a pale blaze on the melon (report 8

180 Table 1; SI video 1). Photo: Roland Edler (Duisburg Zoo). 


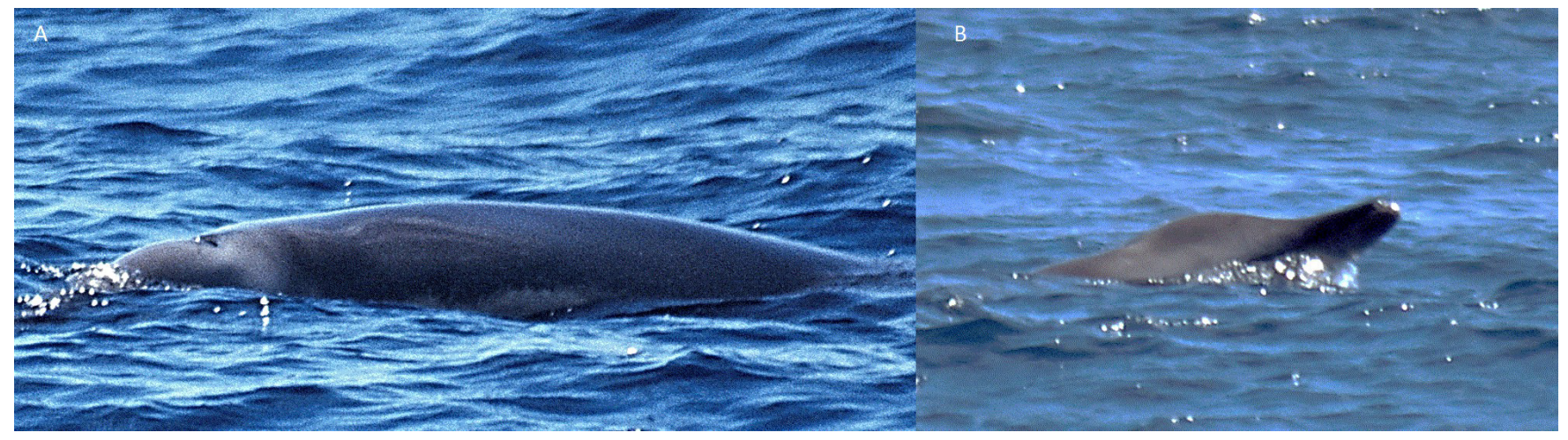

181 Figure 5: Possible True's beaked whale observed off Pico (report 2 Table 1). Photo: Lisa Steiner

182 (Whale Watch Azores).

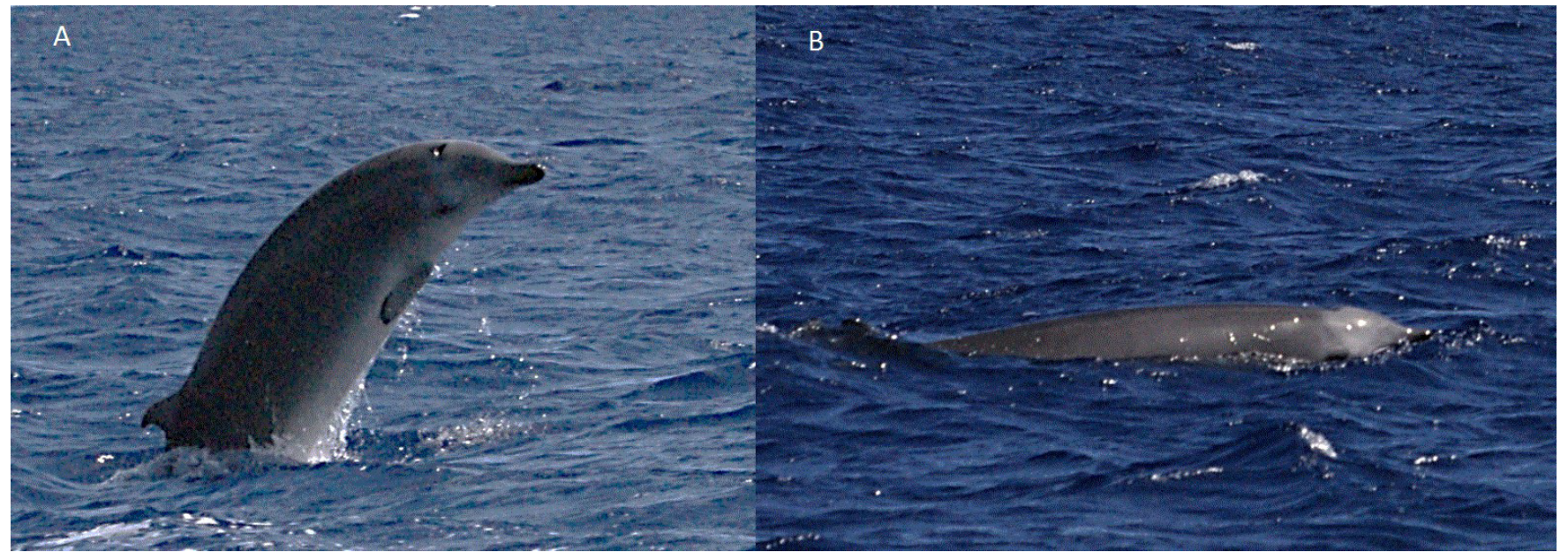

183 Figure 6: True's beaked whale observed off Pico showing a pale blaze on the melon (report 7

184 Table 1). Photo: Petra Szlama (CW Azores).

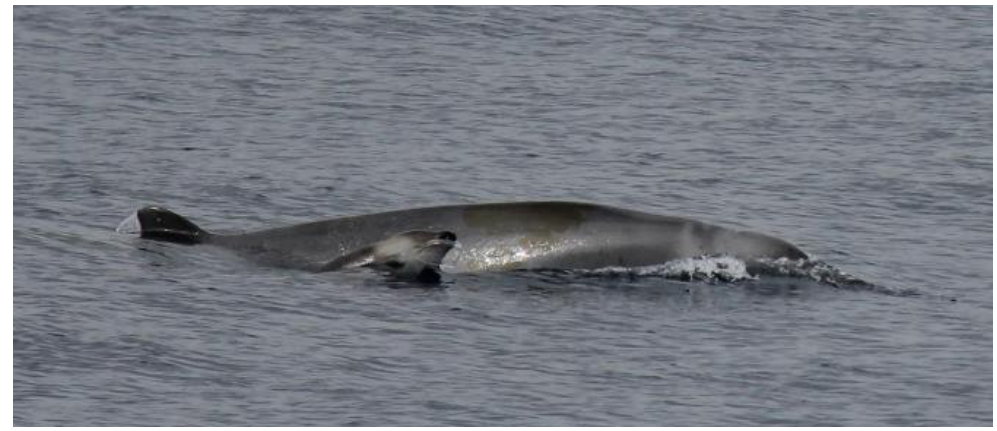

185 Figure 7: True's whale with calf observed south of São Miguel, Azores (report 10 Table 1).

186 Photo: Ida Eriksson (Futurismo). 


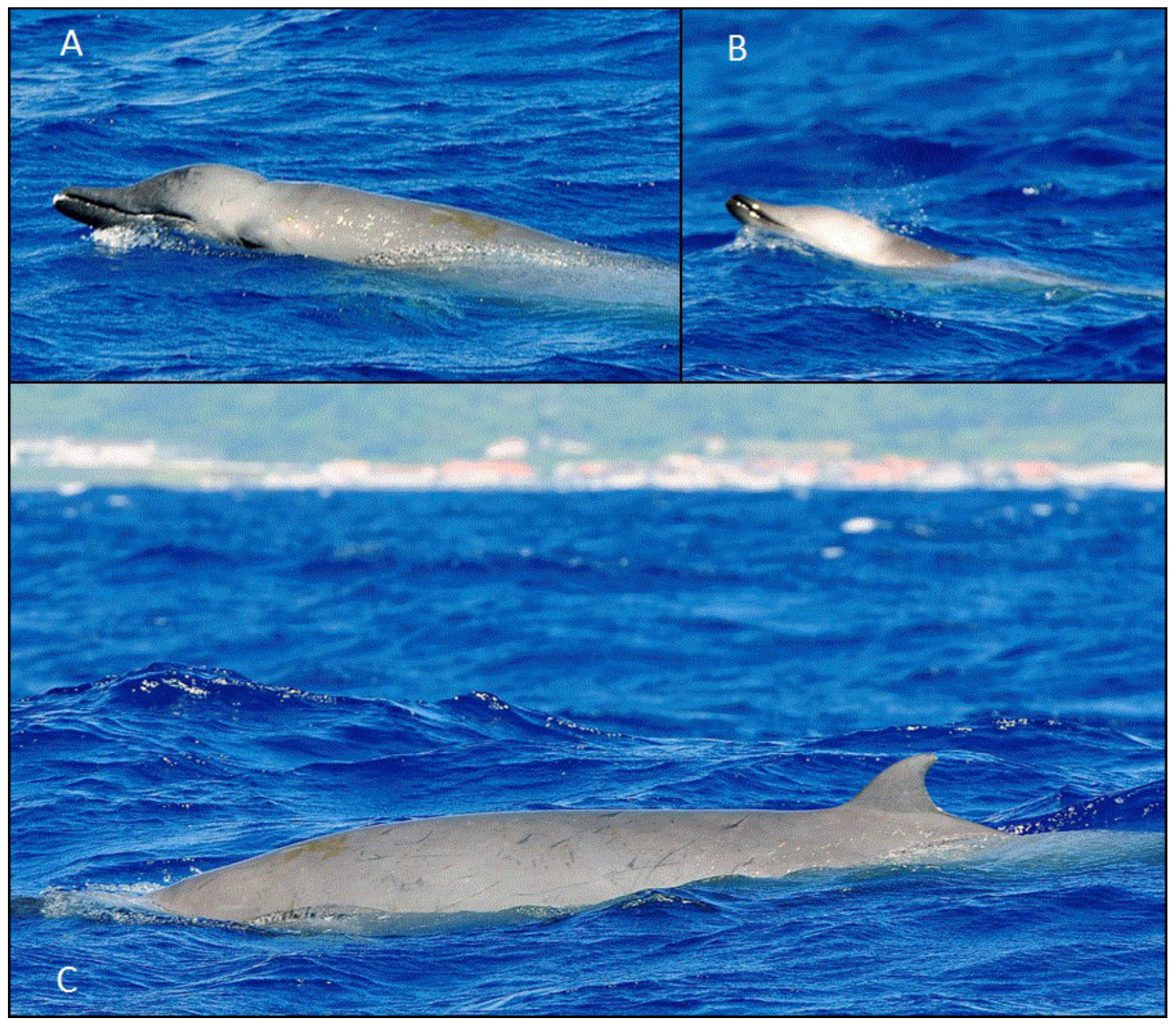

187 Figure 8: True's beaked whale observed off Pico (report 12 Table 1). Photo João Quaresma (Es188 paço Talassa).

189 Three live sightings were also recorded in the Canary Islands. Only one was classified as sure: a

190 group of four True's beaked whales observed in 2009 for 8 min during a cetacean research cruise

191 performed by the Society for the Study of Cetaceans in the Canary Islands Archipelago (SECAC,

192 Figure 9, report 5 in Table 1). The whales were estimated to measure 3.5 to $4.5 \mathrm{~m}$ in length; the

193 largest whale did not present erupted teeth and was tentatively classified as an adult female. Two 
194 shorter sightings of True's or Gervais' beaked whales were impossible to identify with certainty

195 to species level and were classified as possible True's beaked whale and possible Gervais' beaked

196 whale. These sightings were recorded by the Cetacean and Seabird Sighting Network of the

197 Canary Islands “CETAVIST" (www.aviste.me) (Figures 10 and 11; reports 9 and 11 in Table 1).

198 CETAVIST undertook 1300 surveys onboard passenger ferries from December 2012 to October

199 2016; these surveys were performed by volunteer observers resulting in a heterogeneous

200 observation effort in the different inter-island channels of the archipelago.

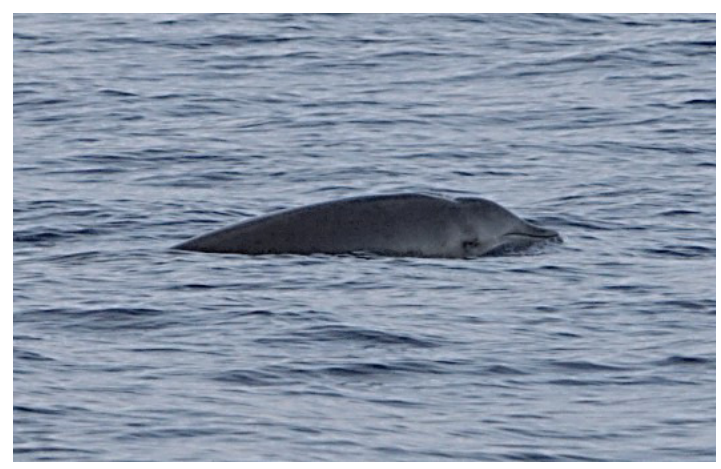

201 Figure 9: True's beaked whale observed off Lanzarote (report 5 Table 1). Photo: Vidal Martín

202 (SECAC).

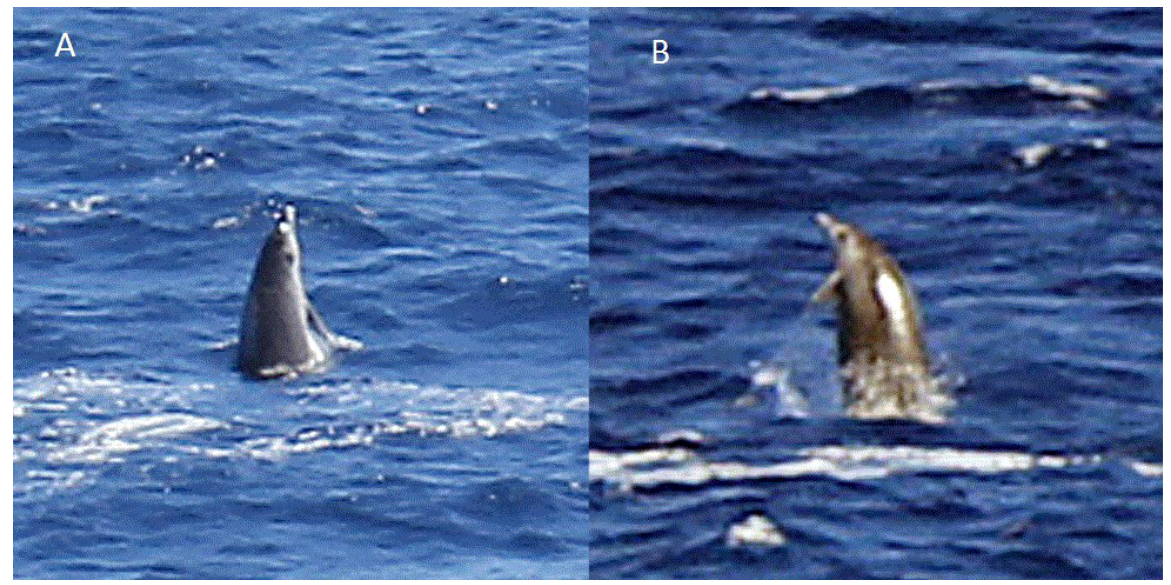

203 Figure 10: Probable Gervais' beaked observed at the Canary Islands (report 9 Table 1). The

204 identification of this animal as True's or Gervais' is difficult because it is not clear if the white

205 patch on the back is an artefact of the light or a real colouration of the animal indicating a Gervais

206 ' beaked whale. Photos: Cristel Reyes (ULL). 


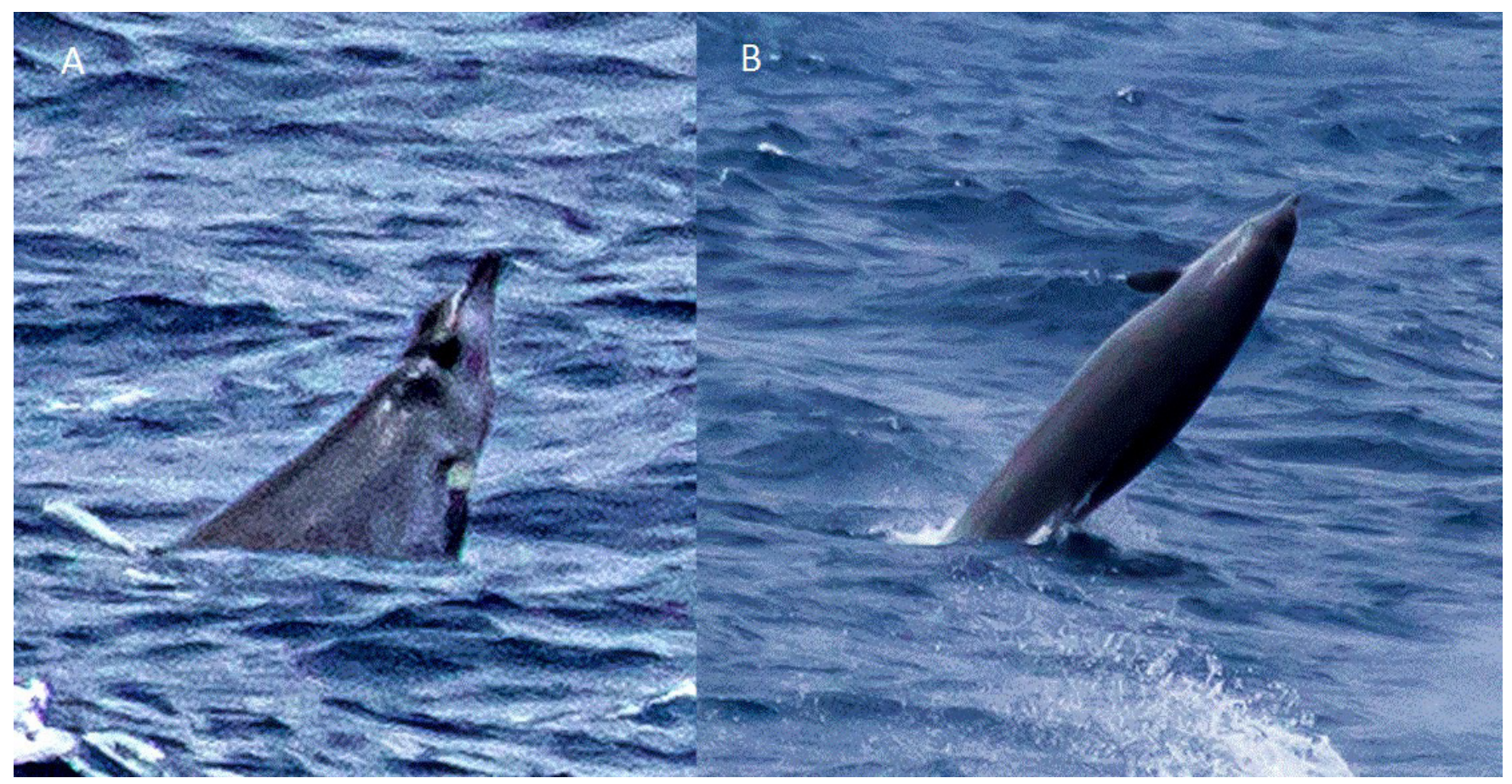

207 Figure 11: Possible True's beaked whales observed in the Canary Islands (report 11 Table 1).

208 Photos: Antonio Portales (Cetavist, ULL).

209 Ethics

210 Samples of two dead whales in the Canary Islands and the Azores were gathered for genetic

211 analysis with authorization obtained from the Cabildo Insular of El Hierro (permit number

212 7021/12_dic_2012) and from the Government of the Azores (permit number 4/CN/2004, issued

213 by the Environment Directorate of the Azores). The sightings data from SECAC were gathered

214 under research permit number 659125 MAOT/15202 from the Spanish Ministry of Agriculture

215 and Environment (MAGRAMA). Sightings gathered opportunistically from regular ferry and

216 permitted whale watching/educational boat operations did not require specific research ethics

217 authorisations or government permits. 
218 RESULTS

219 Strandings and genetic analysis.

220 Genetic sex identification confirmed that both the whale that stranded on El Hierro (Canary

221 Islands) and the whale found drifting in the Faial-Pico channel (Azores) were males. Robust

222 support placed both the El Hierro query sequence (mtDNA control region: 98\% bootstrap

223 support; cytochrome $b$ gene: 94\% bootstrap support) and the Azores' query sequence (mtDNA

224 control region: 97\% bootstrap support; cytochrome $b$ gene: 94\% bootstrap support) in a species-

225 specific clade with True's beaked whale sequences using DNA surveillance.

226 Furthermore, both the mtDNA control region and cytochrome $b$ sequences from both the El

227 Hierro and Azores' males closely matched GenBank sequences identified as True's beaked

228 whales (BLAST accessed May and November 2015, respectively). True's beaked whale

229 sequences from whales that had stranded on the Atlantic coast of the U.S.A. (accession numbers

230 U70465.2 and AY579525.1) were the closest matches to both the El Hierro sample (U70465.2:

$23199 \%$ sequence identity, E-value 9e-153 and AY579525.1: 98\% sequence identity, E-value 4e-151)

232 and the Azores' sample mtDNA control region sequences (U70465.2: 98\% sequence identity, e-

233 value 7e-152 and AY579525.1: 100\% sequence identity, E-value 7e-147). The two top matches

234 against the cytochrome $b$ sequence for both samples were: i) a True's beaked whale that stranded

235 on the Atlantic coast of the U.S.A., accession number AY579551.1 (El Hierro sample: 95\%

236 sequence identity, E-value 3e-70; Azores' sample: 99\% sequence identity, E-value 3e-112); and

237 ii) a sequence from a True's beaked whale that stranded in New Zealand, accession number

238 KF435028.1 (El Hierro sample: 94\% sequence identity, E-value 3e-61, Azores’ sample: 95\%

239 sequence identity, E-value 4e-81). The sequences generated in this study have been archived on

240 GenBank (accession numbers Azores CytB: KX375801, KX375802; Azores Dlp: KX150446; El

241 Hierro CytB: KX375803 and El Hierro Dlp KX150445).

242 Live sightings 
243 Photographs and a video recording from a live sighting of True's beaked whales from across

244 Macaronesia revealed individuals with a diagonal pale blaze on the head. Data from report 8

245 (Table 1, Figure 4 and SI video 1) revealed that this blaze extends dorsally from behind the

246 blowhole to the top of the melon and reaches ventrally to the eye and the start of the mouthline.

247 No obvious size differences were observed among the individuals in the group and none of the

248 three whales had erupted teeth. The same pale blaze colouration pattern on the head was present

249 on other whales observed in different encounters off the Azores, including a female-calf pair

250 where both whales showed the pale blaze on their heads (Figure 7; report 10 in Table 1) and a

251 breaching female or subadult male (Figure 6; report 7 in Table 1). In contrast, this pale-coloured

252 blaze was not evident on other individuals identified as possible True's beaked whales in the

253 same archipelago (Figure 5; report 2 in Table 1).

254 Table 1: Reports of strandings (Strand.) and live sightings (Sight.) of True's beaked whales in the 255 Azores and the Canary Islands (CI) with information on location, date, number of whales $\left(\mathrm{N}^{\circ}\right)$ 256 and certainty on the identification ("sure", achieved using molecular genetic markers (G) or 257 morphology (M), or "possible"). Sightings classified as "possible" may be of True's or Gervais" 258 beaked whales. One sighting (\#8 is probably of Gervais' beaked whales). The entities that 259 gathered the reports were: SECAC: Society for the Study of Cetaceans in the Canary Islands 260 Archipelago; WW Azores: Whale watch Azores; UA: University of the Azores; ULL: University 261 of La Laguna; CW Azores whale watch; Master Mind educational program; Futurismo whale 262 watch; Espaço Talassa whale watch. " Sighting with underwater video; * sighting with small calf.

\begin{tabular}{|c|c|c|c|c|c|c|c|c|}
\hline Report & Location & Date (entity) & Lat, $\mathbf{N}$ & Lon, W & Depth & $\mathbf{N}^{0}$ & behaviour & certainty \\
\hline 1. Strand. & Lanzarote, CI & $\begin{array}{c}23 / 03 / 1984 \\
\text { (SECAC) }\end{array}$ & 28.984 & 13.5 & - & 1 & stranded & sure $(\mathrm{M})$ \\
\hline 2. Sight. & Pico, Azores & $\begin{array}{c}07 / 09 / 1994 \\
\text { (WW Azores ) }\end{array}$ & 38.36 & 28.3767 & 1200 & 3 & travelling & possible (M) \\
\hline 3. Strand. & Fuerteventura, CI & $\begin{array}{l}06 / 06 / 2004 \\
(\text { SECAC) }\end{array}$ & 28.1336 & 14.24 & - & 1 & stranded & sure $(\mathrm{M})$ \\
\hline 4. Strand. & Faial, Azores & $\begin{array}{c}11 / 07 / 2004 \\
(\mathrm{UA})\end{array}$ & 38.47 & 28.64 & - & 1 & drifting dead & sure $(G)$ \\
\hline 5. Sight. & Lanzarote, CI & $\begin{array}{c}29 / 09 / 2009 \\
\text { (SECAC) }\end{array}$ & 28.8346 & 13.5915 & 1100 & 4 & travelling & sure (M) \\
\hline 6. Strand & El Hierro, CI & $\begin{array}{c}30 / 11 / 2010 \\
\text { (ULL) }\end{array}$ & 27.268 & 17.914 & - & 1 & stranded & sure $(G)$ \\
\hline 7. Sight. & Pico, Azores & $\begin{array}{c}31 / 07 / 2010 \\
\text { (CW Azores) } \\
\end{array}$ & 38.3396 & 28.3573 & 1300 & 3 & breaching & sure (M) \\
\hline 8. Sight. ${ }^{\#}$ & Pico, Azores & $\begin{array}{c}05 / 05 / 2013 \\
\text { (MasterMind) }\end{array}$ & 38.28 & 28.341 & 1600 & 3 & milling & sure $(\mathrm{M})$ \\
\hline
\end{tabular}




\begin{tabular}{|c|c|c|c|c|c|c|c|c|}
\hline 9. Sight. & Offshore. CI & $\begin{array}{c}27 / 09 / 2013 \\
\text { (ULL) }\end{array}$ & 28.31 & 14.99 & 2500 & 2 & breaching & $\begin{array}{c}\text { Probable } M . \\
\text { europaeus } \\
\text { (M) }\end{array}$ \\
\hline $\begin{array}{c}\text { 10. Sight. } \\
*\end{array}$ & S. Miguel, Azores & $\begin{array}{c}22 / 05 / 2015 \\
\text { (Futurismo) }\end{array}$ & 37.6386 & 25.5101 & 600 & 2 & travelling & sure (M) \\
\hline 11. Sight. & Offshore. CI & $\begin{array}{c}11 / 07 / 2015 \\
\text { (ULL) }\end{array}$ & 28.4503 & 14.7048 & 2500 & 2 & breaching & possible (M) \\
\hline 12. Sight. & Pico, Azores & $\begin{array}{c}\text { 10/08/2016 } \\
\text { (EspaçoTalassa) }\end{array}$ & 38.3242 & 28.3517 & 1250 & 2 & travelling & sure (M) \\
\hline
\end{tabular}

263 A 'white mask' was observed only in the male subadult whale that stranded on El Hierro, the

264 Canary Islands (Figure 1 and report 6, Table 1). This white colouration covering the whole

265 anterior part of the head, including the melon, beak and lower jaw, has not been previously

266 described for this species. The live sightings in the Canary Islands (Figures 9, 10, 11; reports 5, 9,

26711 in Table 1) showed a grey colouration pattern in the melon and pale lower jaw consistent with

268 previous descriptions of the species. The two sightings classified as "possible" True's beaked

269 whales in the Canary Islandswere both observed to breach repeatedly (Figures 10, 11). This

270 behaviour has been observed previously in True's beaked whales (Figure 12) but was observed

271 also in Gervais' beaked whales in the Canary Islands (Figure 13, Supplementary video 2). Given

272 the morphological and behavioural similarities between these two species (Figure 14), we cannot

273 exclude that whales classified as possible True's beaked whales in this paper were, in fact,

274 Gervais' beaked whales. 


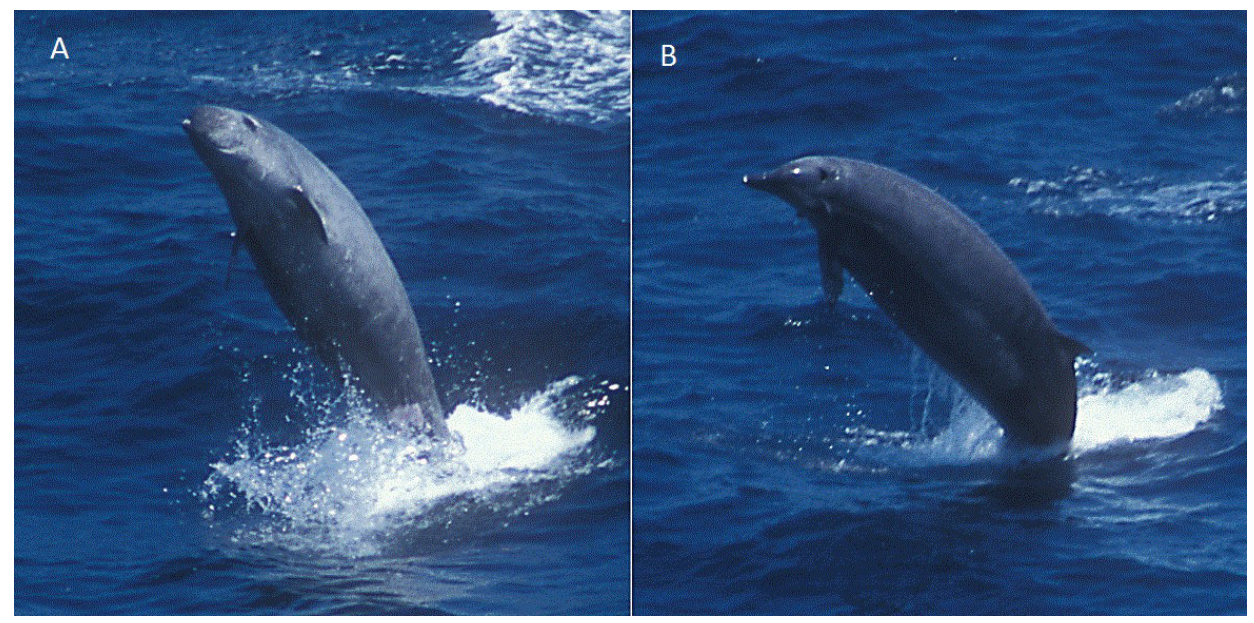

275 Figure 12. True's beaked whale breaching at the Bay of Biscay. Photos. Dylan Walker (WCA).

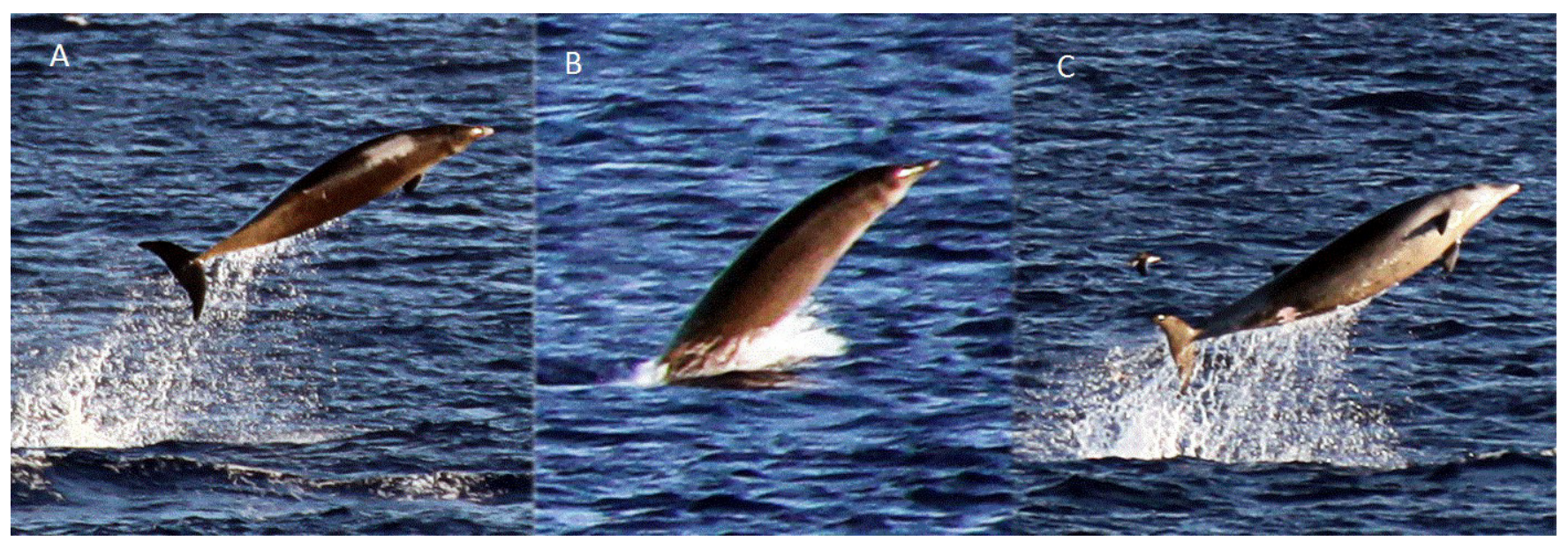

276 Figure 13: Gervais' beaked whales observed south of La Gomera in the Canary Islands (SI Video

277 2). Photos: Michael Scheer (M.E.E.R)

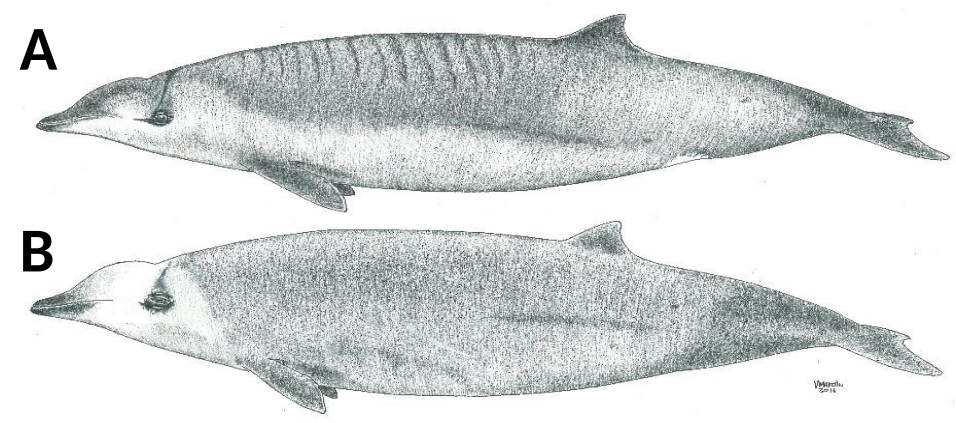

278 Figure 14. Schematic drawing showing differences between Gervais' (A) and True's (B) beaked

279 whales. Note the more pronounced melon of True's beaked whales and the lines in the dorsum 
280 of Gervais' beaked whales. These lines are not present in all individuals of Gervais' beaked

281 whales, but have never been observed in True's beaked whales. The genital white patch shown

282 here in Gervais' may appear in True's beaked whales also. Drawing by Vidal Martín 283 (SECAC).

\section{DISCUSSION}

285 New records of data-scarce species, such as True's beaked whales, are highly valuable in 286 increasing our knowledge about the morphology, behaviour and distribution of these species.

287 True's beaked whales in the North Atlantic are described as greyish in colouration. Some 288 individuals show a dark eye mark and a dark blaze in the upper part of the body from behind the 289 blowhole to past the dorsal fin; some animals may show a pale ventral colouration, sometimes 290 extending to the lower jaw, while other animals may have a pale blaze on their melon (Weir et al., 291 2004; Jefferson et al., 2015). Differing colour patterns have been found for individuals from the 292 southern hemisphere. For example, a female stranded in South Africa showed a whitish dorsal 293 colouration including the dorsal fin and extending to the tail peduncle (Ross, 1984).

294 The True's beaked whale stranded in El Hierro (Canary Islands) had a clearly delimited white 295 mask covering the anterior part of the head from the blowhole and the gular grooves to the 296 rostrum (Figure 1). This pigmentation pattern does not seem to be the result of a post mortem 297 discolouration. In fact, beaked whale colouration tends to darken after stranding because of 298 decomposition, a phenomenon that does not explain the striking white colouration pattern on the

299 head of the whale stranded on El Hierro (A. van Helden, T. Pusser, pers. comm.), but might 300 increase the contrast between the white head and the grey body after stranding. However, the 301 animal might have stranded alive and was in a fresh state when the photographs were taken. This 302 would suggest that the contrasting white cephalic patch observed in the specimen stranded in El 
303 Hierro was present in the living animal. It cannot be dismissed that this unique colour pattern

304 might be an ontogenetic trait. However, this pattern was not observed on the calf nor on any of

305 the other individuals reported in this paper, some of which were likely to be subadults as the

306 whale stranded at El Hierro.

307 The white head colouration described for True's beaked whales increases the probability of

308 confusing this species with Cuvier's beaked whales in sightings when the beak is not observed.

309 Cuvier's beaked whales often have a white colouration on their rostrum and frontal part of the

310 head. Moreover, the female True's beaked whale observed with a calf off the Azores (Figure 7)

311 had a neck and melon colouration very similar to one of the typical head and neck colour patterns

312 shown by Cuvier's beaked whales (e.g. www.cetabase.info whale code ZCH15

313 http://bit.ly/1sbuzVA), underlining the possibility of misidentifying these two species when the

314 beak is not observed.

315 In contrast with its mother, the calf in Figure 7 shows a very distinctive head colouration with a

316 white diagonal band observed in other live sightings of True's beaked whales. The light colour

317 blaze on the melon may be a common feature for True's beaked whales inhabiting the North

318 Atlantic: it has been observed off the Azores in whales of different age classes, from a calf to

319 adult or subadult animals, and previously in the eastern North Atlantic (Weir et al., 2004). A

320 similar light coloured head blaze has been observed in True's beaked whales of both sexes and

321 with different sizes in the western North Atlantic, albeit the pale colour disappears rapidly in

322 stranded whales (T. Pusser, pers. comm.). This suggests that the pale blaze in the melon may pass

323 unnoticed in strandings unless stranded animals are very fresh.

324 In contrast with the colouration patterns described above, some True's beaked whales in the

325 North Atlantic tend to be more uniformly grey, although they may have a small pale mark in the

326 genital-anus area

327 (http://vertebrates.si.edu/mammals/beaked whales/pages/mmi/mmi sp_pg7.htm) (Weir et al., 
328 2004). A whale with this mark was photographed at the Bay of Biscay (Figure 12) and identified

329 as a True's beaked whale thanks to the consistent location of white points at the tip of the lower

330 jaw in several successive photographs, strongly suggesting that these points are the teeth of the

331 whale. A white genital patch, similar to that described in Trues's beaked whales, was observed in

332 a live sighting and strandings of Gervais' beaked whales in the Canary Islands (Figure 13;

333 unpublished data from the Canary Islands Stranding Network by V. Martín and M. Carrillo).

334 True's and Gervais' beaked whales in the North Atlantic have several similar morphological

335 features that challenge their differentiation at sea: the relatively short beak, mostly straight

336 mouthline, overall colouration and dark eye patches. Figure 14 shows a schematic view of the

337 morphological differences between True's and Gervais' beaked whales, including a straighter

338 mouthline in True's than in Gervais', slightly upwards edge of the mouthline in True's; a pale

339 band on the melon of True's (not always present); and a distinctive pattern of pale/dark stripes (or

340 a pale patch) frequent in the dorsum of Gervais' beaked whales (also not always present). Also, a

341 cue to differentiate these species is the pronounced and rounded melon of True's beaked whales,

342 contrasting with the relatively more flat-topped melon of Gervais' beaked whales sloping gently

343 towards the beak (Figures 13, 15). However, this may be difficult to judge from photos taken

344 from different perspectives. When present and visible, scarring patterns can also be used to

345 distinguish between species due to the different position of the erupted teeth in males. While

346 True's beaked whales show parallel and linear scars with small gaps between adjacent scars,

347 Gervais' whales are expected to have single linear scars (Weir et al., 2004). Parallel scars are

348 visible in Figure 5 (report 2 in Table 1), suggesting that these animals were indeed True's beaked

349 whales. 


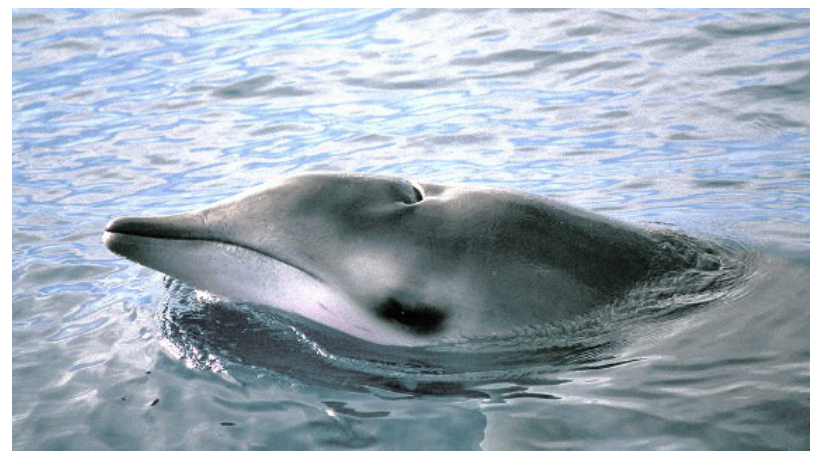

350 Figure 15. Gervais's beaked whale observed off Tenerife (Canary Islands). Note the head 351 morphology of this whale in comparison with True's beaked whales. Photo: Sergio Hanquet.

352 Variability in colour patterns is not surprising for ziphiids. These animals often undergo 353 ontogenetic changes in colouration, and this trait can vary even among individuals of the same 354 size and sex class (Mead, 2009). For this reason, molecular markers providing definite 355 identification among ziphiid species (Dalebout et al., 2004; Thompson et al., 2013) should be 356 used, where possible, to confirm identification obtained using morphological cues (Dalebout et 357 al., 2002; Constantine et al., 2014). Intraspecific variability in colouration for many ziphiids, as 358 well as similarities in general colouration patterns, size/morphology and behaviour among most

359 Mesoplodon species, challenge taxonomic identification at sea. This may cause a bias when 360 assessing the relative abundance of Mesoplodon species in the North Atlantic. Animals for which 361 recognition is challenging will be often classified during surveys as unidentified beaked whales,

362 while recognizable animals will be classified to species level. This will result in an apparent 363 lower relative abundance of species difficult to recognize at sea.

364 Given the presence of True's beaked whales in the Azores and the Canary Islands, it would be 365 expected that this species also occurs in the area between both archipelagos, including Madeira.

366 However, knowledge about the distribution of beaked whales in the eastern North Atlantic Ocean 367 is limited by the relative scarcity of offshore cetacean surveys in Macaronesia. Strandings and 
368 sightings of True's and possible True's beaked whales in the Azores and Canary Islands occurred

369 from March to November (Table 1). However, sample size is too low to infer any conclusion

370 about seasonality in occurrence. The scarcity of sightings of True's beaked whales may reflect a

371 low abundance and/or a general preference for deep waters far from the slope where limited

372 survey effort has been made. The latter is supported by the near lack of sightings of True's

373 beaked whales in relatively nearshore deep waters along the slope of the Canary Islands where

374 other beaked whale species are found routinely. Seasonal surveys in coastal deep waters off the

375 Canary Islands up to $1800 \mathrm{~m}$ depth in the last decade have recorded only one sighting of True's

376 beaked whales, while Cuvier's, Blainville's and Gervais' beaked whales are observed or strand

377 year round (Aguilar de Soto, 2006; Martín, 2011 and unpublished data; Arranz et al., 2014). Most

378 sightings of True's beaked whales reported in this paper occurred at deeper depths (Table 1)

379 although not far from the slope (Figure 16), showing that True's beaked whales visit deep waters

380 near the coast in some areas. The sighting in shallower waters included a small calf (report 10

381 Table 1). Preference of mother-calf pairs for coastal deep waters in oceanic archipelagos has been

382 suggested for other species such as Blainville's beaked whales (Claridge 2013).

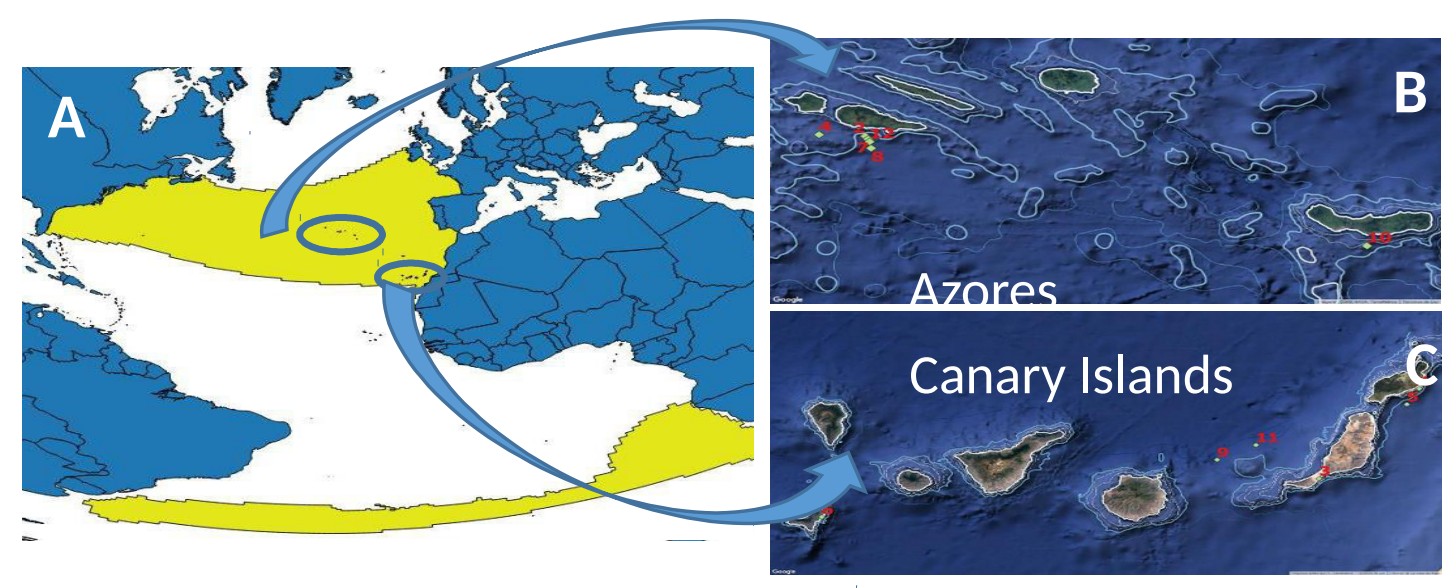

383 Figure 16: B,C: locations of the reports of True's beaked whale included in this paper. The

$3841000 \mathrm{~m}$ depth contour is marked as a thicker light blue line. A: distribution of the species in the 
385 Atlantic, courtesy of the Digital Beaked Whale Atlas of GIS in Ecology, based on data from

386 MacLeod

et

al.

(2006)

387 (http://www.gisinecology.com/Digital_Beaked_Whale_Atlas/Accessing_Data_From_The_DBWA.htm)

388 The relative abundance of live sightings of True's beaked whales in deep coastal waters off the 389 Azores, and to some extent off the Canary Islands, suggests that these archipelagos could be ideal

390 areas to research True's beaked whales in the wild. This is relevant because the identification of

391 hot-spots where some species of beaked whales are found with reliability has provided most of

392 our current knowledge about the natural behaviour of ziphiids (Hooker et al. 1999; Tyack et al.,

393 2006; Baird et al., 2006; Minamikawa et al., 2007; Aguilar de Soto et al., 2012; Claridge 2013).

394 The disjointed global distribution of True's beaked whales has led some authors to suggest that

395 there may be some degree of genetic isolation between the populations of the southern and 396 northern hemispheres (MacLeod et al., 2006; Dalebout et al., 2007). These authors propose that

397 more research is required in order to assess if the northern and southern hemisphere populations

398 might represent different species. The precedents for this include cetacean species that were

399 thought to have an anti-tropical distribution and were finally separated as different species:

400 Hector's and Andrews' beaked whales. M. hectori and M. bowdoini, were separated from M.

401 perrini and $M$. carlhubbsi, respectively. Furthermore, right whales (Eubalaena spp.) were

402 separated into three species (Rosenbaum et al., 2000): the southern right whale (E. australis),

403 with circumpolar distribution in the southern hemisphere, and the North Atlantic (E. glacialis)

404 and North Pacific (E. japonica) right whales. The results of the genetic analysis shown here

405 suggest a potential genetic structure with a phylogeographic pattern for True's beaked whales, as

406 the sequences from the Canary Islands and Azores' matched most closely those True's sequences

407 on GenBank from the North Atlantic. However, more data are required to test this hypothesis. 
408 Given adequate sampling, a global analysis of connectivity would provide useful in 409 understanding gene flow among the seemingly disparate areas of distribution of True's beaked 410 whales worldwide.

\section{ACKNOWLEDGEMENTS}

412 Thanks to the Insular Government (Cabildo) of El Hierro, to the Government of the Canary 413 Islands and to MAGRAMA for providing permit to access to the True's beaked whale stranded at 414 El Hierro. Thanks also to the ferry companies Armas, Fred Olsen and Trasmediterránea for 415 embarking observers of the CETAVIST sighting net, and thanks to the enthusiastic work of these 416 volunteering observers. Thanks to Sergio Hanquet and to Antonio Portales for their photographs 417 of Gervais' and probable True's beaked whales, respectively, observed off the Canary Islands. 418 Thanks to Colin MacLeod for his kind permission to use the distribution map of True's beaked 419 whale from the Digital Beaked Whale Atlas of GIS in Ecology. Also, thanks to T. Sneddon and 420 D. Steel for help in the laboratory and to A. van Helden, T. Pusser, M. Arbelo, B. Brederlau, E. 421 Pérez-Gil, J. Mead and R. Pitman for helpful comments on the reports of this paper. We are 422 grateful to researchers in Madeira (Filipe Alves, Luis Freitas) and Cape Verde (Vanda Marques 423 Monteiro, Evandro Lopes and Cornelis Hazevoet) for their information on True's beaked whales

424 from these archipelagos. Thanks also to the academic editor of this article J. Reimer, and to K. 425 Thompson and an anonymous reviewer for their positive comments which contributed to improve 426 this paper.

\section{REFERENCES}

428 Aasen E., Medrano J.F. 1990. Amplification of the ZFY and ZFX genes for sex identification in 429 humans, cattle, sheep and goats. Nature Biotechnology 8:1279-1281. 
430

431

Aguilar de Soto N. 2006. Acoustic and diving behaviour of pilot whales (Globicephala macrorhynchus) and Blainvilles beaked whales (Mesoplodon densirostris) off the Canary Islands. Implications for the effects of human impacts. Dr. Phil. Thesis. University of La Laguna. Canary Islands. Spain.

Aguilar de Soto N., Madsen P.T., Tyack P., Arranz P., Marrero J., Fais A., Revelli E., Johnson M. 2012. No shallow talk: Cryptic strategy in the vocal communication of Blainville's beaked whales. Marine Mammal Science 28:E75-E92.

Altschul, S. F., W. Gish, W. Miller, E. W. Myers, and D. J. Lipman. 1990. Basic local alignment search tool. J. Mol. Biol. 215:403-410.

Arranz P., Borchers D.L., Aguilar de Soto N., Johnson M.P., Cox M.J. 2014. A new method to study inshore whale cue distribution from land-based observations. Marine Mammal Science 30(2):810-818.

Bachara, W. and Gullan, A. 2016. First stranding record of a True's beaked whale (Mesoplodon mirus) in Mozambique. Unpublished report to Cetal Fauna. Report WB2016/1.

Baird R.W., Webster D.L., McSweeney D.J., Ligon A.D., Schorr G.S., Barlow J. 2006. Diving behaviour of Cuvier's (Ziphius cavirostris) and Blainville's (Mesoplodon densirostris) beaked whales in Hawai'i. Canadian Journal of Zoology 84:1120-1128.

Baker C.S., Medrano-Gonzalez L., Calambokidis J., Perry A., Pichler F., Rosenbaum H., Straley J.M., Urban-Ramirez J., Yamaguchi M., Von Ziegesar O. 1998. Population structure of nuclear and mitochondrial DNA variation among humpback whales in the North Pacific. Molecular Ecology 7:695-707.

Brito Hernández A. 2010. Biogeografía y conservación de la biodiversidad marina en la Macaronesia. Revista de la Academia Canaria de Ciencias 22:215-232.

Claridge D.E. 2013. Population ecology of Blainville's beaked whales (Mesoplodon densirostris). Dr. Phil. Thesis. University of St Andrews. UK 
455 Constantine R., Carroll E., Stewart R., Neale D., van Helden A. 2014. First record of True's 456 beaked whale Mesoplodon mirus in New Zealand. Marine Biodiversity Records 7:e1.

457 Dalebout M. 2002. Species identity, genetic diversity, and molecular systematic relationships 458 among the Ziphiidae (beaked whales). Dr. Phil. Thesis. University of Auckland.

459 Dalebout M.L., Mead J.G., Baker C.S., Baker A.N., Helden A.L. 2002. A new species of beaked 460 whale Mesoplodon perrini sp. N. (Cetacea: Ziphiidae) discovered through phylogenetic 461 analyses of mitochondrial DNA sequences. Marine Mammal Science 18:577-608.

462 Dalebout M.L., Baker C.S., Mead J.G., Cockcroft V.G., Yamada T.K. 2004. A comprehensive and 463 validated molecular taxonomy of beaked whales, family Ziphiidae. Journal of Heredity 95:459-473.

Dalebout M.L., Robertson K.M., Frantzis A., Engelhaupt D., Mignucci-Giannoni A.A., RosarioDelestre R.J., Baker C.S. 2005. Worldwide structure of mtDNA diversity among Cuvier's beaked whales (Ziphius cavirostris): implications for threatened populations. Molecular Ecology 14:3353-3371.

Dalebout M.L., Baker S.C., Steel D., Robertson K.M., Chivers S.J., Perrin W.F., Mead J.G., Grace R.V., David Schofield T. 2007. A divergent mtDNA lineage among Mesoplodon beaked whales: molecular evidence for a new species in the tropical Pacific? Marine Mammal Science 23:954-966.

Dixon J., Frigo L. 1994. The Cetacean Collection of the Museum of Victoria. An Annotated Catalogue. Australian Deer Foundation, Victoria, Australia.

475 Freitas L., Dinis A., Nicolau C., Ribeiro C., Alves F. 2012. New records of cetacean species for 476 Madeira Archipelago with an updated checklist. Boletin Museu Municipal Funchal 62 477 (334): $25-43$. 
478 Hazevoet C.J., Monteiro V., López P., Varo N., Torda G., Berrow S., Gravanita B. 2010. Recent data on whales and dolphins (Mammalia: Cetacea) from the Cape Verde Islands, including records of four taxa new to the archipelago. Zoologia Caboverdiana 1:75-99.

Hooker S.K., Baird R.W. 1999. Deep-diving behaviour of the northern bottlenose whale, Hyperoodon ampullatus (Cetacea: Ziphiidae). Proceedings of the Royal Society of London B: Biological Sciences 266:671-676.

Jefferson T.A., Pitman R.L., Webber M.A. 2015. Marine Mammals of the World, 2nd Edition.

Gilson A, Syvanen M, Levine K, Banks J (1998) Deer gender determination by polymerase chain reaction: validation study and application to tissues, bloodstains, and hair forensic samples from California. Calif Fish Game 84: 159-169.

Kearse M., Moir R., Wilson A., Stones-Havas S., Cheung M., Sturrock S., Buxton S., Cooper A., Markowitz S., Duran C., Thierer T., Ashton B., Meintjes P., Drummond A. 2012. Geneious Basic: An integrated and extendable desktop software platform for the organization and analysis of sequence data. Bioinformatics 28:1647-1649.

MacLeod C.D., Perrin W.F., Pitman R., Barlow J., Ballance L., D Amico A., Gerrodette T., Joyce G., Mullin K.D., Palka D.L., others 2006. Known and inferred distributions of beaked

Martín V. 2011. Short Note: A Sowerby's beaked whale (Mesoplodon bidens) stranded in the Canary Islands: the most southern record in the Eastern North Atlantic. Aquatic Mammals 37:512-519.

McCann C., Talbot F.H. 1964. The occurrence of True's beaked whale (Mesoplodon mirus True) in South African waters, with a key to South African species of the genus. In: Proceedings of the Linnean Society of London. Wiley Online Library, 137-144. 
503 Mead J.G. 1989. Beaked whales of the genus Mesoplodon. In: Ridgway S.H. \& H. ed. Handbook 504 of Marine Mammals. London: Academic Press, 349-430.

505 Mead J.G. 2009. Beaked whales, overview. In: Perrin W.F, Würsig B, Thewissen J.G.M. eds. 506 Encyclopedia of marine mammals. San Diego: Academic Press, 81-84.

507 Minamikawa S., Iwasaki T., Kishiro T. 2007. Diving behaviour of a Baird's beaked whale, 508 Berardius bairdii, in the slope water region of the western North Pacific: first dive records $509 \quad$ using a data logger. Fisheries Oceanography 16:573-577.

510 Moore J.E., Barlow J.P. 2013. Declining abundance of beaked whales (Family Ziphiidae) in the $511 \quad$ California Current large marine ecosystem. PLoS ONE 8:e52770.

512 Rosenbaum H.C., Brownell R.L., Brown M.W., Schaeff C., Portway V., White B.N., Malik S.,

513 Pastene L.A., Patenaude N.J., Baker C.S., others 2000. World-wide genetic differentiation 514 of Eubalaena: questioning the number of right whale species. Molecular Ecology 9:1793$515 \quad 1802$.

516 Ross G.J.B. 1969. Evidence for a southern breeding population of True's beaked whale. Nature $517 \quad 222: 585$.

518 Ross G.J.B. 1984. The smaller cetaceans of the south-east coast of southern Africa. Annals of the $519 \quad$ Cape Provincial Museums (Natural History) 15:173-411.

520 Ross H.A., Lento G.M., Dalebout M.L., Goode M., Ewing G., McLaren P., Rodrigo A.G., Lavery 521 S., Baker C.S. 2003. DNA Surveillance: web-based molecular identification of whales, 522 dolphins, and porpoises. Journal of Heredity 94:111-114.

523 Sambrook T, Fritsch E.F, Maniatis T. 1989. Molecular Cloning: A Laboratory Manual. Cold 524 Spring Harbour Laboratory Press. Cold Spring Harbour, New York, USA.

525 Silva M.A., Prieto R., Cascão I., Seabra M.I., Machete M., Baumgartner M.F., Santos RS. 2014. 526 Spatial and temporal distribution of cetaceans in the mid-Atlantic waters around the 527 Azores. Marine Biology Research 10:123-137. 
528 de Souza S., Siciliano S., de Sanctis B., Caso F. 2004. Uma baleia-bicuda no meio do caminho:

529 Primeiro registro de Mesoplodon mirus (True, 1913) para Brasil. 11th Meeting of South

530 American Aquatic Mammals Specialists. Quito. Ecuador.

531 Spalding M.D., Fox H.E., Allen G.R., Davidson N., Ferdaña Z.A., Finlayson M., Halpern B.S.,

532 Jorge M.A., Lombana A., Lourie S.A., Martin K.D., Mcmanus E., Molnar J., Recchia

533 C.A., Robertson J. 2007. Marine ecoregions of the world: a bioregionalization of coastal $534 \quad$ and shelf areas. BioScience 57:573.

535 Thompson K.F., Millar C.D., Baker S.C., Dalebout M., Steel D., van Helden A.L., Constantine R. 536 2013. A novel conservation approach provides insights into the management of rare ceta$537 \quad$ ceans. Biological Conservation 157:331-340.

538 Tove M. 1995. Live sighting of Mesoplodon C.F. M. mirus, True's beaked whale. Marine mam$539 \quad$ mal Science 11:80-85.

540 Tyack P.L., Johnson M., Aguilar de Soto N., Sturlese A., Madsen P.T. 2006. Extreme diving of 541 beaked whales. Journal of Experimental Biology 209:4238-4253.

542 Vonk R., Martin V. 1988. First list of Odontoceti from the Canary Islands, 1980-87. In: Evans PGH ed. 2nd Ann. Conf. of the European Cetacean Society.

544 Weir C.R., Stokes J., Martin C., Cermeño P. 2004. Three sightings of Mesoplodon species in the 545 Bay of Biscay: first confirmed True's beaked whales (M. mirus) for the north-east $546 \quad$ Atlantic? Journal of the Marine Biological Association of the UK 84:1095-1099. 